\title{
The Role of Chemistry and its Learning to Improve 21st Century Skills in Revolutional Industry 4.0 Era
}

\author{
Suyanta \\ Universitas Negeri Yogyakarta \\ Yogyakarta, Indonesia \\ suyanta@uny.ac.id
}

\begin{abstract}
Technologies at the industrial revolution 4.0 (also referred to as Industry 4.0) which has grown exponentially and progressed at rapid pace largerly take impact on many of other fields covering manufacturing, economy, health care, and education. Therefore, Indonesia entails proper preparations to stay competitive among other nations. As a consequence, challenges that must be faced by human resources are more complex and unpredictable. Education has a crucial role to play in improving the human resources competencies. Chemistry learning as the part of education in a whole gives contribution to students with global competence, known as 21 st century skills, to compete strictly. However, growing students' global competence put a lot of effort for educators. One of the key strategies that can be applied in learning process to support students' global competence is STEM education. Chemistry learning based on STEM education can improve skills to identify problems until make its solution. These skills finally can prepare students for a productive life to be able create and develop better innovation mainly in chemistry field.
\end{abstract}

Keywords - 21st century skills, chemistry learning, industrial revolution 4.0., STEM

\section{INTRODUCTION}

Industrial revolution 4.0 is a concept that has become an important anchor in many group discussions in the past few years due to its advance technologies. The technologies, i.e internet of things (IoT) and artificial intelligence (AI), are revolutionizing traditional manufacturing processes. IoT are designed to communicate devices, engines, sensor, and people each other (Maria, Shahbodin, \& Pee, 2016). People gradually can develop computation capacity providing big data. As a result of this development, the boundary between the real and virtual world is increasingly blurring, giving birth to what are known as cyber-physical systems (CPS) (FICCI, 2017; Gleason, 2018).

The emergence of the term of industrial revolution 4.0 certainly caused the question on how about the previous industrial revolution era. Water and steam power hitting the mechanical production toward more systematic and efficient forms of manufacturing at around 1800s was the initial year of industrial revolution 1.0. Steam power technology in stuff production supports mechanization in industry process. This crucial invention has transformed human performance that originally used muscle, water, and wind power to move everything. Nevertheless, human resources at that period were still productive. The second industrial revolution began in 1900s with the invention of the internal combustion engine. This invention led to an era of rapid industrialization through interchangeable parts, electricity power, and industry standard concept. This is followed by the third industrial revolution where the implementation of electronics and information technology to automate production was characterized as the industrial revolution 3.0 started in 1960s. This era was catalysed by mobile and automatic engines that were robotic and computer (Klaus, 2016; Maria, et al., 2016).

Industrial revolution 4.0 is the area where the change, as well as the options, is palpable and real. It is combine virtual world tangible human, engine, and data connectivity. New technologies that merge the physical, digital and biological world is tangibled in robot, mobile computer devices, artificial intelligence, public services, etc (Gleason, 2018; Klaus, 2016; Maria, et al., 2016). Every work fields including bussines, manufacturing, health care, and education are changing driven by advanced technologies of industrial revolution 4.0. Additionaly, those fields is already increasing broader and challenging transformation (Aulbur, Arvind, \& Bigghe, 2016). Work force will need to be agile and able to jump between very different types of tasks and context. On top of this, the number of workspaces with high level of complexity will increase. Hence, the need of all work fileds to recruit human resources that meet high standards, such as able to adapt to the rapid technology development, able to successfully answer challenges with creative responses, and able to handle with complex work environments will become main priority (R\&D Solutions Elsevier, 2017).

The biggest challenge faced by all nations around the world including Indonesia in the era of industrial revolution 4.0 is developing capacity for academic achievement and retention of knowledge among graduates. Likewise, schools and universities are being reshaped, as are systems of education. In order to increase human resources performance, education will have to change, quickly, many aspects that no longer relevant with this era. Thus, educators have a responsibility to manage students' competencies growth. The competency needed in industrial revolution 4.0 is global competence also known as $21^{\text {st }}$ century competence.

\section{MATERIALS AND METHODS}

\section{Educational Revolution 4.0}

The landscape of education has changed across the enormous growth in industrial revolution. In the other 
words, education also responds to the each steps of industrial revolution and the response made education reform aimed at improving the quality of education a core priority. School and universities should begin to focus more closely on improving students' life skill in order to have the ability to work in the midst of intense global competetition (FICCI, 2017). This is a grand project requiring sustained effort and persistence. The evolution of education has also started since a few decades ago where education 1.0 has been begun. Learning process in ancient ages was still conservative and passive during education 1.0 where teachers acted as a solely source of knowledge and students received given informations. In this era, not only the standardized curriculum was lack and not set, but also the learning source was limited (FICCI, 2017; Gleason, 2018).

The invention of the printing press technology was the initial sign to the education 2.0 eras. It had profound effect on the number of learning source and literacy level. The period witnessed massive scientific research where inquiries, new ideas, and innovations were encouraged. This scientific work done by the scholars and followed by the publication has become basis of the further knowledge. The number of prestigious universities, such as Cambridge, Oxford, and Stanford universities also grew rapidly. Education 2.0 drove education system to encourage students to be able tomanage economic and social life (FICCI, 2017; Gleason, 2018; Maria, et al., 2016).

The education 3.0 which was generally attributed to the computerization and web-based interconnectivity gave a tremendous impact on learning sources. It is important to note that learning sources were originally print media switched to digital through internet. The technology has brought educators and students to an environment where acces to information is immediate and free. In line with the development of learning media, teacher centered slowly began left out where teachers-instructed classroom has been no more the way knowledge is disseminated (FICCI, 2017; Gleason, 2018; Maria, et al., 2016).

In education 4.0, learning is connected to the learner, focused on the learner, demonstrated by the learner, and led by the learner. Technology innovation in education field such as online course is personalization of learning media and expected to completely displace traditional inperson learning source. Blended learning which virtual environment combined with interface course is believed offer great knowledge transmission to the students. Substancial changes to the education 4.0 will be required to allow for students to increase life skills for meeting the need of industry 4.0 workspace (FICCI, 2017; Mammino \& Zunin, 2015).

\section{Students Future Needs in Industrial Revolution 4.0}

Literacies in industrial revolution 4.0 are also undergoing dramatic change, so new literacies are needed as assets to encounter the era of industrial revolution 4.0. It will be an essential mission for the educators to find a way to educate the next generation to invent, to create,, and to discover through new literacies. There are three new literacies which prepares students to compete in a labor market (Aoun, 2017; Rigg, 2018; Saepudin, 2019).
1. Data literacy

Students will need data literacy to manage the flow of big data. They are expected to have the capabilities of reading, analyzing, and utilizing information.

2. Technological literacy

This literacy is related to the students ability to understand the workings of machines and technological applications. Students are required to be able to work based on technology products to get positive results.

3. Human literacy

Students of the future will meet requirements to understand how to deal with technology; have human skills, such as empathy and communication; and have critical thinking and problem solving skills. These standards are sought for among all work space in the future.

\section{Trends of Education 4.0}

A new vision of learning elevates students to learn abilities and information are required as well as to distinguish the source to become familiar with these skill and learning. Fisk (2017) and Hussin (2018) describe nine trends related to industrial revolution 4.0 .

1. Diverse time and place

Advanced technologies in the revolution industry 4.0 open wide opportunities for students to be free to learn anytime anywhere, e-learning tools also support great opportunities for remote, and self-managed learning. Students are digital native who are at ease with the mobile and computing devices and look for information on the internet. Online courses as are nimble of footed provider anytime anywhere study allows students to make a note and summarize important points and to make question list that can discussed at class. Therefore, learning process inside class can be more effective and focus on giving task. This method is known as flipped classroom.

2. Personalized learning

In the future will be a lot of changes in ways of teaching and learning. Students with the high mastering concept will become a mentor to others and will be introduced to harder task, whereas the students who are still experience difficulties with a subject should do more practice under the instructor supervision. This method can promote positive learning experience and boost students' confidence about their own abilities.

3. Free choice

Students freely choose media learning that are feel necessary for them. Similarly to the personalized learning experience, they have a choice in determining and modifying how they want to learn. Learning model that can be applied to facilitate students to be creative in their learning are lended learning, flipped classrooms and BYOD (Bring Your Own Device).

4. Project based

Project based learning (PjBL) is very helpful for students in applying obtained knowledge and can increase both soft and hard skills. PjBL can effectively teach students as a basis of organizational, collaborative, nd time management skills. Moreover, it 
can promote students capabilities to become a part of doing business in future academic career.

5. Field experience

The rapid progress of technology makes it possible to efficiency learn certain fields, thus making more space for the acquisition of abilities involving human understanding and interface interaction. A curriculum reorientation is certainly needed because the literacy in the industrial revolution 4.0 has changed. Hence, institutions open wide chance for students to obtain real-world skills that are representative to their jobs fulfill internships, entrepreneurship, and collaborative learning.

6. Data interpretation

Mathematic which is one of the late literacy will become more irrelevant and be replaced by sophisticated technology (software), resulting from that situation data analysis is no more done by human. Human interpretation of these data will become a much more important part of the future curricula. The fundamental disciplinary of data literacy is to use reasoning skill to be able both to infer and interpret trends and to use the information in the digital world (big data).

7. Exam will change completely

Many educators believe that Q\&A (question and answer) assessment is become might not suffice because it is only designed to cram material into students which will then be forgotten. Educators worry that exam might not validity measure what students should be capable of when they enter their first job. The alternative assessment that can be used is to assess students when they are working on projects in the field.

8. Student ownerships

With a growing population and advanced technologies, a society slumps into decay and eventually ruin without innovation. During the revolutional industry 4.0, institutions spawned changes in a massive way in terms of many factors such as the curriculum design. Because the main goal of mass institutions is targeting transfer of skills and preparation for a wide variety of unpredictable future, curriculum needs to reorient. Students' critical input on the content and durability of their courses will be a new overview and useful for maintaining a curriculum.

9. Mentoring will become more overcome

The next generations have a huge chance to be a center during the learning process.by helping others others develop and maintain valuable knowledge and skills, lifelong learning is necessary to alleviate social inequality. Thus, students will be so independent in their learning process that mentoring becomes essential to student achievement.

\section{Global Competence as Competency in Education 4.0 Era}

Based on past experience and present experience, education always work through the future. The objective of education is preparing students to live in the future where all problem which will be faced, is more complex and cannot be predicted. Therefore, Schools or Universities should prepare their students not only knowledge but also skills that can be used to develop and to apply their knowledge in real life. Furthermore, students should be equipped with the good attitude in order that their knowledge is not abused and can be used for human importance.

Along with the times, the demanding of education as well develop. The industrial revolution 4.0 era give impact to education area which cause the demanding of education is more complex, no exception in chemistry education. Students not only sued for mastering chemistry knowledge but also for applying knowledge to solve problems in real life especially regional, national and international issues (global issues). Schools should prepare their students in order to proficient globally. Competency which is required to solve global issue is called global competence or $21^{\text {st }}$ century competence.

Generally, global competence is defined as skills, value, knowledge, and attitude which should be prepared and should be possessed for students to thrive in global citizenship interconnected era. OECD (2018) define global competence as capability to investigate global issue, capability to understand and to respect the difference of perspective, capability to take action for commonweal, and capability to participate in open, proper and powerful interactions across society. Global competence covered four domain, that are investigate the world, recognize perspective, communicate ideas and take action (Mansilla \& Jackson, 2011). At glance, fourth domains of global competence emphasize on process skills in discovery of knowledge.

1. Investigate the world

Investigate the world is skill for investigating global issues. In this domain, students should use various learning resources to identify the fact. Therefore it can be analyzed to draw a good respond with a good argument in order to produce a good conclusion.

\section{Recognize perspective}

Recognize perspective is skill for identifying issue based on his or her own perspective. In this domain, students should explain her or his own perspective in identifying problems.

\section{Communicate idea}

Communicate ideas is skills for communicating ideas effectively in front of various audiences. In this domain, students should express her or his opinion in front of audiences, use the right technology and media in communicating with audiences and choose the right technique for effective communication.

\section{Take action}

Take action is skills for decision making based on his or her own idea to solve problem. In this domain, students should draw up the good decision to solve problem.

Based on fourth domains of global competence can be believed that global competence can deliver empirical and practical knowledge and skills. It means that applying global competence in learning process, students' skills and knowledge succeed more meaningful. It is caused by students take active role in obtaining her or his own knowledge. Global competences are divided into six 
competencies, i.e. (Council of Ministers of Education Canada, 2018)

1. Critical thinking and problem solving

Critical thinking and problem solving are competencies that used to identify problem, to analyze problem and to interpret information for making decision as problem solution. Deep learning can be achieved when the learning process can be linked to real life. So, students have authentic experiences.

2. Innovation, creativity and entrepreneurship

Innovation, creativity and entrepreneurship are competencies that used to apply idea into action for responding public need. Ability for associating idea or product to contribute in global issues settlement include leadership, taking risks, independent/unpredictable thinkingand experimenting with new procedures, methods, or perspectives, through inquiry research.

3. Learning to learn

Learning to learn is competence that used to train independence and awareness in learning that influenced by motivation, persistence and self-controlled.

4. Communication

Communication is competence that used to comprehend and to communicate idea (such as reading, writing, listening and speaking ) in various context with various audiences and objectives. Effective communication covers understanding local and global perspectives, societal and cultural contexts and applying various communication media appropriately, capably, securely and with respect.

5. Global citizenship and sustainability

Global citizenship and sustainability are competencies that used to reflect different perspectives about world and to understand crucial issues settlement such as ecology, social and economy. It include the result of knowledge, motivation, attitude and skills required an ethos of engaged citizenship, with appreciation for diversity of society, perspectives, and the capacity to visualize and work in the better future.

6. Collaboration

Collaboration is competence to interact with another, interpersonal and intrapersonal competencies required for engaging effectively and ethically in a team.

With provision of students' global competencies, students are expected to live well in the future, to solve problems properly and to take action without contradicting with norms and values.

\section{Chemistry Education in Education 4.0 Era}

Nowadays, Indonesia is facing the industrial revolution 4.0 era with the high competition level. The changing that must be made is improvement of human resources. Schools and universities have important role to provide students becoming high quality human resources and ready competing for facing challenges in the industrial revolution 4.0 era. Therefore schools and universities need to better understand and review what the competencies are needed and must be possessed by students. The intended competencies are global competencies. It is not easy to do to develop that competencies. So, the teachers or lecturers should make a decent attempt in order to make it happen. One of the effective method that should be done is to change the learning model or approach with STEM.

STEM is learning approach that integrates between science, technology, engineering and mathematics (The National Science Foundation, 2017). Application of STEM approach can embed students' enthusiasm to do investigation and can cultivate skills as perseverance, collaboration and application of knowledge. STEM based learning will provide maximum result when it starts form an early age. Knowledge, skills and abilities that are honed through STEM based learning are required in entire field of work (USA Department of Education \& American Institute of Research, 2016).

Granovskiy (2018) declared that students can solve problem and design solution based on their knowledge and experiences by connecting science, technology, engineering, and mathematics. Leshner and Scherer (2018) proposed that STEM based learning will shape students into high quality human resources by:

1. Stimulating curiosity;

2. Granting students to develop their intellectual intelligence;

3. Training students to acquainted, to formulate, to solve problem and to communicate their solution;

4. Granting students opportunities to explore knowledge;

5. Shaping students into human resources who can conduct basic research and applied research that directly beneficial to innovation and economic growth.

STEM based chemistry learning means that implementation of chemistry learning is integrated technology, engineering and mathematics (Susanti, 2018). The example of the application of STEM based chemistry learning in high school are

1. Chemistry integrated with industry

Chemistry integrated with industry can be performed by entering the industrial problem, especially problem related to chemistry, such as chemical equilibriumin industry, separation process and refining metals, and chemical waste industry management. These problems are incorporated into learning process as a case study problem, so students understand the use of chemistry theory in industrial field. (Fiman, 2018).

2. Chemistry integrated with technology

Chemistry integration with technology can be carried out during research when applying instrument to analyze research product. Moreover, it can be done when look for reliable learning resources (e-book and research journal), record the research data, organize data into visual form either graphs or tables, make report and presentation of research result

3. Chemistry integrated with mathematics

Chemistry integrated with mathematics can be seen in the chemical problems related calculation. Mathematics is used to solve chemical problem related to a number, sch as $\mathrm{pH}$ of the acid based, thermochemistry and many more. Moreover chemistry integration with mathematics can be seen in reading skills and can be interpreted the data analysis in table or graphs forms (Susanti, 2018). 
STEM based learning combined with PjBL (project based learning) learning model can develop students' skills to solve global issues, so students can identify problems and can draw their solution about the issues. In the end, these skills are able to shape students becoming high quality of human resources, engineering and developing technological innovation the future, especially in the chemistry field.

\section{RESULTS OF RESEARCH AND DISCUSSION}

\section{Nanotechnology}

Researchers and engineers have focused on developing nanomaterials that can benefit human life in the near future due to its nature: strength, thin, and have great chemistry reactivity than macroparticles. Nanotechnology is engineering in the manufacture of materials, functional, and devices in the nanoscale by controlling at the atomic level (European Communities, 2016). Sub-microscopic particles have different nature with macroscopic particle. Newton law can explain macroscopic particles while sub-microscopics is no more relevant with it. Therefore, quantum mechanic is the best way to explain sub-micrsocopic world.

\section{A. Nanotechnology of The Past}

Nanotechnology is enhancing the quality of everyday products clothing, food, medicine, electronic, etc by the use of nanomaterials. Nevertheless, ideas about nanotechnology have been emerged at the ancient ages when people had developed many nanosized objects, but they did not understand about its nature and process. Since then, researcher starts to give considerable attention to nanotechnology development. There were many nano objects developed by the people in ancient times that described by Tolockho (2018).

1. Natural fabrics (flax, cotton, wool, silk)

The kind of natural fabrics is not ordinary due to the production process. It was developed network of pores with the size of $1-20 \mathrm{~nm}$ (nanopore). As a result of nanopore structure, it possess high quality properties: keep the fabrics away from unpleasant odor and quickly dry.

2. Hair dye in ancient Egypt

Natural vegetative dyes, henna, and black hair dyes were mainly used by Egyptians to colour their hair. The research conducted by analyzing hair samples turned out that lime, lead oxide, and small amount of water were combined to made hair dyes (Tolochko, 2018). Galenite (lead sulfide) contained in hair sample had formed by the reaction of dyeing pasta with sulfur and had the diameter of $5 \mathrm{~nm}$ (Walter et.al., 2006). It resulted in provided and stable dyeing. Natural black colour on hair caused by pigment called melanin.

3. Licurg's bowl at the British museum

The Licurg's bowl at the British museum was an outstanding product of glass maker due to the preferential properties, which can change colour, depends on its location. This phenomenon occurred by impacts of Plasmon excitation of electrons with metal nanoparticles when it illuminated (Freestone et al., 2007; Schaming \& Remita, 2015). Researcher analyzed that its fragment consist of common soda-lime-quartz glass; $1 \%$ of gold and silver; and $0,5 \%$ of manganese as components (Tolochko, 2018).

4. Multi-colored church stainedglass in Europe

The stainedglass achieved high intention by its perfection. Recently, researcher found that it contained additives of gold and nanoparticles of other metals, which were gold and silver nanoparticles and other metals (Tolochko, 2018). The red colour was made from combination of glass and gold nanoparticles, whereas the yellow red was made from combination of glass and silver nanoparticles (Schaming \& Remita, 2015).

5. Damask steel

When crusade, European knights could not confront the muslims' strength of blades. These blade is extraordinary strength. It was made by Damask steel. Researcher analyzed that damask steel fragment had nanofiber structure contained carbon nanotube and nanowires (Reibold et al., 2006; Tolochko, 2018). It estimated that special thermomechanical process of steel occured when manufacturing steel due to its steels' structure.

\section{B. Nanotechnology in the future}

Future technological advancements are supported by three interconnected technologies, viz nanotechnology, bioengineering, and information technology. Future technologies are developed based on combination of these interconnected technologies.

1. Food industry

Nanotechnologies applied in this industries is used to develop food packaging in order to more solid, lighter, corrosion resistance and not wasteful (Rai,\& Rai,2015). These technology can provide protection food from harmful pathogenic organism.

\section{Textile industry}

Nanoparticles used to this industries are silver nanoparticles, cooper, titanium, zinc and silica. Researcher began to develop titanium dioxide nanoparticles for self-cleaningand UV-blocking. Zinc nanoparticles can be used to protect fabric from UV ray. Silica nanoparticles are used to increase fabric resistance to wrinkles. Antimicrobial is used to protect fabric from microbes that can damage the texture and can cause odor.(Rai \& Rai,2015).

3. Construction industry

The benefits of nanotechnology in construction industry in the future are (Vijaykumar et al., 2016):

a. Titanium oxide nanoparticles are used for removing pollutant. These particle can clean concrete properties sulphur hydrophiliocity, make window glass become anti-fogging and anti-dirty, protect from UV ray and photocatalysis. Furthermore titanium oxide nanoparticles are also used for self cleaning in outside wall.

b. Carbon nanotubes in the manufacturing of ceramics serves to maintain ceramics durability and to prevent cracks. 
c. Silver nanoparticles in the manufacturing of paint have function as anti-microbial, so it can prevent the growth rate of fungus and moss.

d. Zinc oxide nanoparticles are used in coatings and paints.

e. Copper nanoparticles have function as corrosion resistance in the manufacturing of steels layer.

f. Nanoclay in combination with nylon serves to upgrade hardness level in the structure of plastic polymer materials.

4. Electronic industry

Application of nanotechnology in the electronic industry serve to discover alternative material for changing silicon material on electronic devices manufacturing (Rai,\& Rai,2015). The selection of carbon nanomaterials such as carbon nanotube and graphene as substitute for silicon based on better electrical properties than silicon. So, current electronic device products have smaller and thinner size than previous product (Vijaykumaret al., 2016).

5. Medical

Application of nanotechnology in medical field is focused on drugs delivery (new formulation for drugs and gene therapy), tissue engineering (producing and repairing damaged tissues), and sub-micrometer medical devices (Vyas \& Gurjar, 2016; Vijaykumaret al., 2016). For example carbon nanofiber use to deliver drugs to blood cells. Nanofibers' ability is to deliver drugs to navel of illness directly. Nanofiber has used in various medical application such as bandage for binding up wound and thread for sewing wound, so it can minimize the risk of infection and blood loss.

6. Paper and pulp industry

Application of nanotechnology in paper and pulp industries means to make waterproof paper, magnetic paper and bacteria free paper. These paper are made by nanocelloulose synthesized naturally in wood. It is composed of nanofibrileswith its width $20 \mathrm{mn}$ (Rai,\& Rai,2015).

7. Automotive industry

There are application nanotechnology related to automotive industry i.e. body car coating and structural application. Body car coating use aluminium nanoparticles and aluminium oxide nanoparticles. Its function are making scratch resistance surface and protecting against mold and odor growth. Structural appliction aim to reduce car weight but stay strong to support cars' frame. So, it can be economized fuel using. Thermoplastic Olefin nanocomposite materials are used for automotive parts (Rai,\& Rai,2015).

\section{CONCLUSIONS}

The emerging of advanced technologies has been cited as a key signal of the rapid development of science and technologies. Chemistry as the part of basic knowledge plays a strategic role to pave the future needs. Therefore, chemistry learning is an ideal engine for preparing students to cope with industrial revolution 4.0.

\section{REFERENCES}

[1] Aoun, J. E. (2017). Robot-proof: Higher education in the age of artificial intelligence. Cambridge: The MIT Press.

[2] Aulbur, W., Arvind, C., \& Bigghe, R. (2016). Skill development for industry 4.0. BRICS Council Report.

[3] Council of Ministers of Education Canada. (2018). Global Competence. Retrieved from http://www.cmec.ca/682/Global Competence.html

[4] European Communities. (2016). Industry 4.0, Advanced Material (Nanotechnology). Regional Innovation Monitor Plus 2016.

[5] FICCI. (2017). Leapfrogging to education 4.0: Student at the core. FICCI Higher Education Summit, India.

[6] Fisk, P. (2017). Education 4.0 ... the future learning will be dramatically different, in school and throughout life. Retrieved from http://www.thegeniusworks.com/2017/future-education-youngeveryone-taught-together

[7] Freestone, I. Meeks, N., Sax, M., Higgitt, C. (2007). Lycurgus cup- a roman nanotechnology. Gold Bulletin. 40(4), 270-277.

[8] Gleason, N.W. (2018). Higher education in the era of the fourth industrial revolution. Singapore: Palgrave Macmillan.

[9] Granovskiy, B. (2018). Science, technology, engineering, and mathematics (STEM) education: An overview. Congressional Research Service Report.

[10] Hussin, A.Z. (2018). Education 4.0 made simple: Ideas for teaching. International Journal of Education \& Literacy Studies, 6(3).

[11] Mammino, L. \& Zunin, V.G. (2015). Worldwide trends in green chemistry education. Cambridge: Royal Society of Chemistry.

[12] Mansilla, V. B., \& Jackson, A. (2011). Education for global competence: Preparing our youth to engage the world. New York: Asia Society.

[13] Maria, M., Shahbodin, F., Pee, N.C. (2016). Malaysian higher education system towards industry 4.0 - current trends overview. AIP Conference Proceedings of the 3rd International Conference on Applied Science and Technology.

[14] OECD. (2018). Preparing our youth for an inclusive and sustainable world: The OECD PISA global competence framework. Paris: OECD

[15] R\&D Solutions Elsevier. (2017). Industry 4.0: Top challenges for chemical manufacturing. White Paper Elsevier.

Rai, S. \& Rai, A. (2015). Nanotechnology - The secret of fifth industrial revolution and the future of next generation. Nusantara Bioscience. 7(2): 61-66

Reibold, M., Paufler, P., Levin, A.A., Kochmann, W., Patzke, N., Meyer, D.C., Carbon nanotube in an ancient Damascus sabre. Nature. Volume 16 hal 286

Rigg, P. (2018). How will universities prepare students for industry 4.0? Retrieved

from https://www.universityworldnews.com/post.php?story=2018100912 3052681

Saepudin, B.S. (2019). Revolusi industry 4.0, apakah itu? Dan pengaruhnya terhadap dunia pendidikan. Retrieved from http://disdikkbb.org/?news=revolusi-industri-4-0-apakah-itu-danpengaruhnya-terhadap-dunia-pendidikan

Schaming, D \& Remita, H. (2015). Nanotechnology: form the ancient time to nowadays. Found Chem. Nanotechnology seminar: irrational fears, realistic expectations in Paris 4-5 juni 2012

Schwab, Klaus. (2016). The fourth industrial revolution. Geneva: World Economic Forum

Susanti, L.Y., Hasanah, R., Khirzin, M.H. (2018). Penerapan media pembelajaran kimia berbasis science technology engineering and mathematics (STEM) untuk meningkatkan hasil belajar siswa SMA/SMK pada materi reaksi redoks. Jurnal Pendidikan Sains, 06(02), 32-40 
The National Science Foundation USA. (2017). What is STEM education. Retrieved from https://www.nsf.gov/news/news_summ.jsp? cntn_id $=243502$

Tolochko, N.K. (2018). History of Nanotechnology. In Valeri Kharkin, Chunli Bai, Sergey Kapitza, Osama O. Awaldelkarim (Eds), Nanoscience and Nanotechnologies (pp. 1-18). Paris: UNESCOEOLSS Joint Committee

USA Department of Education \& American Institute of Research. (2016). STEM 2026: A Vision for innovation in STEM education. USA Department of Education Report.
Vijaykumar, G., Tile, H.S., Suraj, B.M., Sahana, S.G. (2016). Recent trends in nanotechnology and its future scope - A review. International Journal on Emerging Technologies. 7(2): 377-385

Vyas, L \& Gurjar J. (2016). Review on nanotechnology \& its future aspect. Ijrias. 1(2), 12-14.

Walter, P., Welcomme, E., Hallegot, P., Zaluzec, N.J., Deeb, C., Castaing, J., Veyssiere, P. Breniaux, R., Leveque, J., Tsoucaris, G. (2006). Early use of PbS Nanotechnology for an ancient hair dyeing formula. $\begin{array}{llll}\text { Nano } & \text { Lett. } & 6(10): & 215-2219\end{array}$ 